\title{
Computer vision-based assessment of motor functioning in schizophrenia: Use of smartphones for remote measurement of schizophrenia symptomatology
}

Anzar Abbas ${ }^{1}$, Vijay Yadav $^{1}$, Emma Smith², Elizabeth Ramjas², Sarah B. Rutter ${ }^{2}$, Caridad

Benavides $^{2}$, Vidya Koesmahargyo ${ }^{1, *}$, Li Zhang ${ }^{1}$, Lei Guan ${ }^{1}$, Paul Rosenfield ${ }^{2}$, Mercedes

Perez-Rodriguez ${ }^{2}$, Isaac R. Galatzer-Levy ${ }^{1,3}$

${ }^{1}$ AiCure, LLC, New York, NY

${ }^{2}$ Icahn School of Medicine at Mount Sinai, New York, NY

${ }^{3}$ Psychiatry, New York University School of Medicine, New York, NY 
medRxiv preprint doi: https://doi.org/10.1101/2020.07.20.20158287; this version posted July 25, 2020. The copyright holder for this preprint (which was not certified by peer review) is the author/funder, who has granted medRxiv a license to display the preprint in perpetuity.

All rights reserved. No reuse allowed without permission.

\begin{abstract}
Introduction: Motor abnormalities have been shown to be a distinct component of schizophrenia symptomatology. However, objective and scalable methods for assessment of motor functioning in schizophrenia are lacking. Advancements in machine learning-based digital tools have allowed for automated and remote 'digital phenotyping' of disease symptomatology. Here, we assess the performance of a computer vision-based assessment of motor functioning as a characteristic of schizophrenia using video data collected remotely through smartphones.

Methods: 18 patients with schizophrenia and 9 healthy controls were asked to remotely participate in smartphone-based assessments daily for 14 days. Video recorded from the smartphone front-facing camera during these assessments was used to quantify head movement through a pre-trained computer vision model. The ability of head movement measurements to distinguish between patients and healthy controls as well as their relationship to schizophrenia symptom severity as measured through traditional clinical scores was assessed. Results: A logistic regression demonstrated that head movement was a significant predictor of schizophrenia diagnosis $(p<0.05)$. Linear regression between head movement and clinical scores of schizophrenia symptom severity showed that head movement has a negative relationship with schizophrenia symptom severity $(p<0.05)$, primarily with negative symptoms of schizophrenia. Conclusions: Remote, smartphone-based assessments were able to capture meaningful visual behavior for computer vision-based objective measurement of head movement. The measurements of head movement acquired were able to accurately classify schizophrenia diagnosis and quantify symptom severity in patients with schizophrenia.
\end{abstract}


medRxiv preprint doi: https://doi.org/10.1101/2020.07.20.20158287; this version posted July 25, 2020. The copyright holder for this preprint (which was not certified by peer review) is the author/funder, who has granted medRxiv a license to display the preprint in perpetuity.

All rights reserved. No reuse allowed without permission.

\section{1 - Introduction}

Motor abnormalities have been shown to be a characteristic trait of schizophrenia, are present even in antipsychotic-naive patients, predate the onset of psychosis, and have been demonstrated in at-risk populations and in unaffected relatives. ${ }^{1-6}$ Indeed, psychomotor retardation underlies core negative symptomatology of schizophrenia such as the demonstration of blunted facial affect and emotional withdrawal. ${ }^{7-11}$ Though there have been many attempts to diagnose schizophrenia and quantify symptom severity using neurobiology and behavior, ${ }^{12-14}$ little work has been done to objectively measure motor dysfunction to characterize the disorder in clinical research, ${ }^{15-17}$ which could be of particular relevance in assessment of negative symptoms.

Recent advances in the mechanistic understanding of negative symptomatology have led to a number of promising pharmacological and cognitive treatments for negative symptoms of schizophrenia. ${ }^{18-21}$ Such initiatives are important given the lack of FDA-approved treatments for negative symptoms. ${ }^{22}$ However, reliable and change-sensitive measures of negative symptomatology to assess the efficacy of these treatments are sparse ${ }^{23-26}$. With motor dysfunction being an underlying factor of negative symptomatology, accurate measurement of motor functioning can allow for assessment of treatment efficacy during the evaluation of novel investigational treatments.

Several groups have successfully and accurately measured motor functioning as a characteristic of schizophrenia, though only in laboratory-settings ${ }^{27-31}$. While laboratory-based methodologies increase sensitivity and reduce subjectivity in measurement of motor functioning compared to 
medRxiv preprint doi: https://doi.org/10.1101/2020.07.20.20158287; this version posted July 25, 2020. The copyright holder for this preprint

traditional assessments, they are limited in their utility as measurement tools in clinical research given the burden imposed on both patients and clinicians.

The use of 'digital phenotyping' or measurement of disease symptomatology using digital tools has shown significant promise towards objective, scalable, and remote measurement of central nervous system functioning. ${ }^{32,33}$ In schizophrenia, observable behavior associated with the disorder has been successfully quantified using advancements in machine learning. Examples of this include using digital signal and natural language processing methods to measure changes in verbal prosody and speech characteristics such as volume, fundamental frequency, pause characteristics, and sentiment ${ }^{34-39}$ and computer vision to quantify changes in facial expressivity and presence of blunted facial affect, a core negative symptom of schizophrenia. ${ }^{34-38}$ The use of visual data such as videos of patient behavior presents a promising avenue for digital phenotyping given the ubiquitous availability of smartphone cameras alongside advances in computer vision methodologies that can automate the processing and analysis of visual information.

In the current investigation, we examined the ability of head movement measured using computer vision from videos recorded during remote smartphone-based assessments to differentiate individuals with schizophrenia from healthy controls and determine disease severity by comparison of head movement with the Positive and Negative Syndrome Scale (PANSS), a commonly used clinical assessment tool for measurement of schizophrenia severity and the current 'gold standard' for assessment of antipsychotic treatment efficacy. ${ }^{39}$ 
medRxiv preprint doi: https://doi.org/10.1101/2020.07.20.20158287; this version posted July 25, 2020. The copyright holder for this preprint

(which was not certified by peer review) is the author/funder, who has granted medRxiv a license to display the preprint in perpetuity.

All rights reserved. No reuse allowed without permission.

\section{2 - Methods}

Code for all methods and analysis presented in this manuscript is publicly available on GitHub: https://github.com/anzarabbas/ms_headmov_scz.

\section{1 - Participants}

Patients meeting DSM-5 criteria for schizophrenia at Mount Sinai Health System Outpatient Psychiatry Clinics $(n=18$; age $\mu=48.1, \sigma=13.1 ; 11$ females $)$ and healthy individuals from the community ( $n=9$; age $\mu=39.8, \sigma=10.4 ; 5$ females) were consented to participate in a two-week observational study under approval of the Mount Sinai Program for the Protection of Human Subjects and its Institutional Review Board. Participants in the schizophrenia group were on a stable regimen of psychotropic medications, had no recent clinically meaningful change in schizophrenia symptomatology, and were clinically stable in that they were not expected to show significant changes in symptomatology over the course of the two-week observational study.

\section{2 - Data collection}

\subsection{1 - Positive and negative syndrome scale (PANSS)}

The Positive and Negative Syndrome Scale(PANSS) was administered in-person by the study team on the first day of the study on both patients with schizophrenia and healthy control subjects. Healthy individuals were assessed to confirm an absence of schizophrenia symptomatology. Ten individuals from the schizophrenia group were also assessed on the last day of the study i.e. day 14. For those ten individuals, the average of the two scores were used 
medRxiv preprint doi: https://doi.org/10.1101/2020.07.20.20158287; this version posted July 25, 2020. The copyright holder for this preprint (which was not certified by peer review) is the author/funder, who has granted medRxiv a license to display the preprint in perpetuity.

All rights reserved. No reuse allowed without permission.

for all subsequent analyses. Given the patients were clinically stable, the average of the two PANSS scores simply allowed for reduction in noise. From the PANSS, subscale scores were recorded for the positive symptom subscale (P-total), the negative symptom subscale (N-total), and general symptom subscale (G-total) in addition to all individual items within those subscales.

\subsection{2 - Remote smartphone-based video assessments}

All participants were asked to download the AiCure app (www.aicure.com) on either their personal smartphone or a smartphone provisioned to them by the study team. They were then trained by the study team on how to use the app to participate in remote assessments. The remote assessments triggered the participants to perform a brief 1-minute task where they were asked open-ended questions to which they responded freely while a video of their response was captured using the front-facing camera on the smartphone. The open-ended questions were neutral in nature and simply meant to elicit a free verbal response (e.g. "What have you been doing for the past few hours?" and "What are your plans for the rest of the day?"). The assessments were scheduled everyday for the 14 days of the study. The videos collected during these assessments were used to quantify head movement during the participants' responses.

\section{3 - Measurements of head movement}

The software library OpenFace ${ }^{40-42}$ was used to measure frame-wise head movement from the videos collected through the remote smartphone-based assessments. For each frame, the head's position relative to the camera was calculated using pre-trained convolutional neural network-based computer vision models. The software provides a confidence score for every 
medRxiv preprint doi: https://doi.org/10.1101/2020.07.20.20158287; this version posted July 25, 2020. The copyright holder for this preprint (which was not certified by peer review) is the author/funder, who has granted medRxiv a license to display the preprint in perpetuity.

All rights reserved. No reuse allowed without permission.

frame of video denoting the likelihood that it is accurately detecting a face; only frames with a confidence score of $80 \%$ or higher were used for downstream analyses. Framewise measurements of change in euclidean head position in the $x, y$, and $z$ planes were calculated in millimeters as shown in the equation below. From the framewise measurements, mean head movement was calculated across all videos collected from a participant over the course of the study. All measurements of head movement were normalized between 0 and 1 before subsequent data analysis.

$$
\begin{aligned}
& \text { Head movement in frame } n=\sqrt{\left(x_{n}-x_{n-1}\right)^{2}+\left(y_{n}-y_{n-1}\right)^{2}+\left(z_{n}-z_{n-1}\right)^{2}} \text {, where } \\
& x_{n}=\text { head position in the } x \text { plane during the current frame, } \\
& y_{n}=\text { head position in the } y \text { plane during the current frame, and } \\
& z_{n}=\text { head position in the } z \text { plane during the current frame }
\end{aligned}
$$

\section{4 - Data analysis}

Using head movement data collected from all participants in both groups, a multiple logistic regression with maximum likelihood estimation was conducted to model the probability of an individual having a schizophrenia diagnosis based on measurements of head movement, with age and gender as additional predictors in the regression. Using data only from individuals with schizophrenia, separate linear regressions were conducted to determine the relationship between head movement and the PANSS subscale scores in addition to individual items in each of those subscales, with age and gender as confounding variables. The linear regressions were an exploratory analysis to determine the relationship between head movement and individual items on the PANSS and hence multiple comparisons correction was not conducted. 
medRxiv preprint doi: https://doi.org/10.1101/2020.07.20.20158287; this version posted July 25, 2020. The copyright holder for this preprint (which was not certified by peer review) is the author/funder, who has granted medRxiv a license to display the preprint in perpetuity.

\section{5 - Data Availability}

The raw video analyzed in this manuscript is considered Protected Health Information. It was not consented for public use and cannot be published. However, the first level of non-identifiable raw abstractions from that data as well as the derivations used to conduct all analyses will be provided alongside the code.

\section{6 - Code Availability}

Code for all methods and analysis presented in this manuscript is publicly available on GitHub (https://github.com/anzarabbas/ms_headmov_scz).

\section{3 - Results}

\section{1 - Logistic regression}

Data from 9 healthy controls and 18 individuals with schizophrenia was used for the logistic regressions. Head movement, age, and gender were able to significantly differentiate healthy controls and individuals with schizophrenia $\left(L L=-12.13\right.$; Pseudo $\left.r^{2}=0.29 ; p<.05\right)$ with head movement as the only significant predictor $(O . R .=0.04$ (95\% CI: $0.00,0.48) ; z=-2.27 ; p<.05)$ and age demonstrating a marginal effect $(O . R .=1.07(95 \%$ CI: $0.99,1.18) ; z=1.65 ; p<.1)$ (Table 1). 
medRxiv preprint doi: https://doi.org/10.1101/2020.07.20.20158287; this version posted July 25, 2020. The copyright holder for this preprint (which was not certified by peer review) is the author/funder, who has granted medRxiv a license to display the preprint in perpetuity.

All rights reserved. No reuse allowed without permission.

Table 1: Results from multiple logistic regression of head movement, age, and gender with schizophrenia diagnoses.

\begin{tabular}{lcccc}
\hline Variable & Coefficient & Standard Error & $\mathrm{z}$ & $\mathrm{p}$-value \\
\hline Constant & -0.441 & 2.069 & -0.213 & 0.938 \\
Head motion & -5.421 & 2.392 & -2.267 & 0.023 \\
Age & 0.075 & 0.046 & 1.65 & 0.1 \\
Gender & -0.465 & 1.03 & -0.453 & 0.651 \\
\hline
\end{tabular}

\section{2 - Linear regression}

In the data collected from individuals with schizophrenia $(n=18)$, separate linear regressions were conducted with head movement, age, and gender as predictors of each individual item on the PANSS. The results from all of these regressions are detailed in Supplementary Tables 1, 2, and 3. A subset of the results from those regressions are outlined in Tables 2 and 3.

Table 2: Results for the linear regressions conducted with head movement, age, and gender as predictors of PANSS subscale scores.

\begin{tabular}{|c|c|c|c|c|c|c|c|c|c|}
\hline Variable & Predictor & Coefficient & Std. Error & $\mathrm{t}$ & p-value & $\mathrm{F}$ & $\mathrm{R}^{2}$ & Adj. $\mathrm{R}^{2}$ & p-value \\
\hline \multirow[t]{5}{*}{ P Total } & & & & & & 2.013 & 0.301 & 0.152 & 0.158 \\
\hline & Constant & 0.5152 & 0.190 & 2.711 & 0.002 & & & & \\
\hline & Head Motion & -0.3032 & 0.257 & -1.181 & 0.257 & & & & \\
\hline & Age & 0.0007 & 0.003 & 0.204 & 0.842 & & & & \\
\hline & Gender & 0.2057 & 0.092 & 2.248 & 0.041 & & & & \\
\hline \multirow[t]{5}{*}{ N Total } & & & & & & 3.055 & 0.396 & 0.266 & 0.0634 \\
\hline & Constant & 0.5649 & 0.211 & 2.683 & 0.002 & & & & \\
\hline & Head Motion & -0.6383 & 0.284 & -2.245 & 0.041 & & & & \\
\hline & Age & 0.0037 & 0.004 & 0.955 & 0.356 & & & & \\
\hline & Gender & 0.2107 & 0.101 & 2.078 & 0.057 & & & & \\
\hline \multirow[t]{5}{*}{ G Total } & & & & & & 6.200 & 0.571 & 0.479 & 0.0067 \\
\hline & Constant & 0.6209 & 0.139 & 4.457 & 0.001 & & & & \\
\hline & Head Motion & -0.5193 & 0.188 & -2.760 & 0.015 & & & & \\
\hline & Age & 0.0025 & 0.003 & 0.967 & 0.350 & & & & \\
\hline & Gender & 0.2338 & 0.067 & 3.485 & 0.004 & & & & \\
\hline
\end{tabular}


When correcting for age and gender, head movement had a significant negative association with the $\mathrm{N}$-total and G-total scores $(p=0.041$ and $p=0.015$ respectively) but not the P-total score $(p$ $=0.257$ ) (Table 2). Further, when correcting for age and gender, head movement was negatively associated with several individual items on the PANSS (Table 3): N1 blunted affect $(p=0.029)$, $\mathrm{N} 2$ emotional withdrawal $(p=0.012), \mathrm{N} 3$ poor rapport $(p=0.026), \mathrm{G} 7$ motor retardation $(p=$ 0.006), G8 uncooperativeness ( $p=0.040)$, and G12 lack of judgement and insight $(p=0.025)$. 
medRxiv preprint doi: https://doi.org/10.1101/2020.07.20.20158287; this version posted July $25,2020$. The copyright holder for this preprint (which was not certified by peer review) is the author/funder, who has granted medRxiv a license to display the preprint in perpetuity. All rights reserved. No reuse allowed without permission.

Table 3: A subset of the results for the linear regressions conducted with head movement, age, and gender as predictors of individual PANSS items.

\begin{tabular}{|c|c|c|c|c|c|c|c|c|c|}
\hline Dependent variable & Predictor & Coefficient & Std. Err. & $\mathrm{t}$ & $\mathrm{p}$-value & $\mathrm{F}$ & $\mathrm{R}^{2}$ & Adj. $\mathrm{R}^{2}$ & $\mathrm{p}$-value \\
\hline N1 & & & & & & 3.064 & 0.396 & 0.267 & 0.0629 \\
\hline Blunted & Constant & 0.5700 & 0.226 & 2.517 & 0.025 & & & & \\
\hline \multirow[t]{3}{*}{ Affect } & Head Motion & -0.7412 & 0.306 & -2.424 & 0.029 & & & & \\
\hline & Age & 0.0041 & 0.004 & 0.997 & 0.336 & & & & \\
\hline & Gender & 0.2000 & 0.109 & 0.997 & 0.088 & & & & \\
\hline $\mathbf{N 2}$ & & & & & & 4.313 & 0.480 & 0.369 & 0.0237 \\
\hline Emotional & Constant & 0.5566 & 0.191 & 2.911 & 0.001 & & & & \\
\hline \multirow[t]{3}{*}{ Withdrawal } & Head Motion & -0.7483 & 0.258 & -2.898 & 0.012 & & & & \\
\hline & Age & 0.0059 & 0.004 & 1.690 & 0.113 & & & & \\
\hline & Gender & 0.1604 & 0.092 & 1.742 & 0.103 & & & & \\
\hline N3 & & & & & & 2.395 & 0.339 & 0.198 & 0.112 \\
\hline \multirow{3}{*}{ Poor Rapport } & Head Motion & -0.7986 & 0.321 & -2.491 & 0.026 & & & & \\
\hline & Age & -0.0010 & 0.004 & -0.234 & 0.818 & & & & \\
\hline & Gender & 0.1294 & 0.114 & 1.133 & 0.276 & & & & \\
\hline G7 & & & & & & 4.023 & 0.463 & 0.348 & 0.0294 \\
\hline Motor & Constant & 0.6199 & 0.243 & 2.554 & 0.023 & & & & \\
\hline \multirow[t]{3}{*}{ Retardation } & Head Motion & -1.0616 & 0.328 & -3.239 & 0.006 & & & & \\
\hline & Age & 0.0050 & 0.004 & 1.127 & 0.279 & & & & \\
\hline & Gender & 0.1160 & 0.117 & 0.992 & 0.338 & & & & \\
\hline G8 & & & & & & 2.190 & 0.319 & 0.174 & 0.135 \\
\hline \multirow[t]{4}{*}{ Uncooperativeness } & Constant & 0.7052 & 0.224 & 3.154 & 0.007 & & & & \\
\hline & Head Motion & -0.6850 & 0.302 & -2.269 & 0.040 & & & & \\
\hline & Age & -0.0019 & 0.004 & -0.455 & 0.656 & & & & \\
\hline & Gender & 0.1322 & 0.108 & 1.228 & 0.240 & & & & \\
\hline \multirow{4}{*}{$\begin{array}{l}\text { Lack of Judgement } \\
\text { and Insight }\end{array}$} & Constant & 0.4446 & 0.230 & 1.937 & 0.073 & & & & \\
\hline & Head Motion & -0.7751 & 0.310 & -2.500 & 0.025 & & & & \\
\hline & Age & 0.0060 & 0.004 & 1.414 & 0.179 & & & & \\
\hline & Gender & -0.0687 & 0.111 & -0.622 & 0.544 & & & & \\
\hline
\end{tabular}


medRxiv preprint doi: https://doi.org/10.1101/2020.07.20.20158287; this version posted July 25, 2020. The copyright holder for this preprint

(which was not certified by peer review) is the author/funder, who has granted medRxiv a license to display the preprint in perpetuity.

All rights reserved. No reuse allowed without permission.

\section{4 - Discussion}

In the current investigation, we sought to test the hypothesis that motor functioning as measured by the amount of head movement during free behavior, quantified through convolutional neural network-based computer vision models, would serve as a digital marker of schizophrenia symptomatology. We further assessed the ability of digital tools, i.e. remote smartphone-based assessments that capture video of individuals' behavior, to measure schizophrenia symptomatology in an accurate, scalable, and objective manner.

Findings demonstrate that head movement during free responses to scripted prompts delivered over a smartphone and recorded through the front-facing camera significantly differentiated healthy controls from individuals with schizophrenia (Table 1). Further, the exploratory results suggest that slowed head movement is a marker of negative symptomatology of schizophrenia including blunted affect, motor retardation, poor rapport, and emotional withdrawal (Table 2). Additionally, we found preliminary evidence that head movement is associated with uncooperativeness and lack of insight. While the interpretation of this relationship is less straightforward, this may reflect underlying cognitive deficits in schizophrenia associated with negative symptomatology. Our findings align with previously reported motor slowing in individuals with schizophrenia ${ }^{43-46}$ and are consistent with the notion that different types of motor symptoms may correlate with different aspects of psychotic symptoms. ${ }^{47}$

Furthermore, the results demonstrated that motor functioning can be objectively measured using data captured remotely, in the absence of a clinician or a clinical environment, and without the need for any specialized equipment or hardware beyond a smartphone. Video captured of an 
medRxiv preprint doi: https://doi.org/10.1101/2020.07.20.20158287; this version posted July 25, 2020. The copyright holder for this preprint (which was not certified by peer review) is the author/funder, who has granted medRxiv a license to display the preprint in perpetuity.

All rights reserved. No reuse allowed without permission.

individual's behavior during remote smartphone-based assessments was sufficient for measurement of head movement as a behavioral symptom of schizophrenia, and may be sufficient for computationally-based measurement of other behavioral symptoms such as changes in facial expressivity, vocal acoustics, and characteristics of speech. With tools emerging that are able to measure all such behavioral symptomatology using computer vision, digital signal processing, and machine learning ${ }^{34-38,48,48-53}$, these behaviors may be measurable in the same manner that movement behavior was assessed in this investigation.

Abnormalities in motor functioning underlie observable symptomatology in several neurological and neuropsychiatric disorders including Major Depressive Disorder, ${ }^{54,55}$ Parkinson's Disease, ${ }^{56}$ and Autism Spectrum Disorder, ${ }^{57-59}$ among others. Given the transdiagnostic nature of motor symptomatology, remote and scalable methods for its measurement may have utility for assessment of treatment response and/or motor side-effects of treatment in both clinical care and clinical research beyond just schizophrenia. With advancements in computationally-based measurement of other observable behavioral symptomatology such as facial expressivity, speech, and physiology, digital measurements could bring immense utility in the monitoring and diagnosis of mental and physical health using remote tools.

It is important to note key limitations of this study, in particular the multiple comparisons conducted on the modest sample size. With the primary objective of this study being to test the hypothesis that head movement is negatively correlated with schizophrenia diagnosis, the logistic regression provided compelling evidence towards rejection of the null hypothesis. The subsequent linear regressions conducted between head movement and all PANSS items served as 
medRxiv preprint doi: https://doi.org/10.1101/2020.07.20.20158287; this version posted July 25, 2020. The copyright holder for this preprint (which was not certified by peer review) is the author/funder, who has granted medRxiv a license to display the preprint in perpetuity.

All rights reserved. No reuse allowed without permission.

a secondary and exploratory aim, allowing for determination of a relationship between head movement and specific schizophrenia symptomatology. With results from the analysis indicating relationships as would be hypothesized based on prior reports, we present them as preliminary findings with the ultimate goal of expanding such an experiment to a wider patient population, allowing for a more fine-grained analysis of head movement as a digital biomarker of schizophrenia symptomatology.

Finally, this investigation utilized open-source Python-based software, available to all researchers. As an additional measure, the code that implemented the open-source software for this investigation and subsequent analyses of results have been provided by the authors in the Methods section. This allows for the expansion of the experiment to a wider patient population as mentioned above and the independent validation of the computer vision-based measurement of head movement itself and its implementation in this investigation by other researchers in academic and clinical research, following an open-science framework for the development of digital tools for objective, accurate, and scalable measurement of disease symptomatology in both mental and physical health.

\section{5 - Conclusions}

In this investigation, we demonstrate that head movement measured using computer vision from video captured remotely via smartphones demonstrates validity as a marker of schizophrenia and is a promising metric for negative symptom severity. Use of such technology in clinical care and clinical research settings could allow for accurate measurement of disease symptomatology and treatment response in a scalable and accessible manner, which can support development of novel 
medRxiv preprint doi: https://doi.org/10.1101/2020.07.20.20158287; this version posted July 25, 2020. The copyright holder for this preprint (which was not certified by peer review) is the author/funder, who has granted medRxiv a license to display the preprint in perpetuity.

All rights reserved. No reuse allowed without permission.

treatments for schizophrenia and other mental and physical disorders that involve motor symptomatology. 
medRxiv preprint doi: https://doi.org/10.1101/2020.07.20.20158287; this version posted July 25, 2020. The copyright holder for this preprint (which was not certified by peer review) is the author/funder, who has granted medRxiv a license to display the preprint in perpetuity.

All rights reserved. No reuse allowed without permission.

\section{Acknowledgments}

The authors appreciate the involvement of the clinical, research, and operations staff at both

Mount Sinai and AiCure for the development, deployment, and implementation of the

technology presented here and the participants who volunteered to be involved in the research. 
medRxiv preprint doi: https://doi.org/10.1101/2020.07.20.20158287; this version posted July 25, 2020. The copyright holder for this preprint (which was not certified by peer review) is the author/funder, who has granted medRxiv a license to display the preprint in perpetuity.

\section{References}

1. Brekke JS, Raine A, Ansel M, Lencz T, Bird L. Neuropsychological and psychophysiological correlates of psychosocial functioning in schizophrenia. Schizophr Bull. 1997;23(1):19-28. doi:10.1093/schbul/23.1.19

2. Ellegood J, Henkelman RM, Lerch JP. Neuroanatomical Assessment of the Integrin $\beta 3$ Mouse Model Related to Autism and the Serotonin System Using High Resolution MRI. Front Psychiatry. 2012;3. doi:10.3389/fpsyt.2012.00037

3. Morrens M, Docx L, Walther S. Beyond Boundaries: In Search of an Integrative View on Motor Symptoms in Schizophrenia. Front Psychiatry. 2014;5. doi:10.3389/fpsyt.2014.00145

4. Sullivan EV, Shear PK, Lim KO, Zipursky RB, Pfefferbaum A. Cognitive and motor impairments are related to gray matter volume deficits in schizophrenia. Biol Psychiatry. 1996;39(4):234-240. doi:10.1016/0006-3223(95)00135-2

5. Sullivan EV, Shear PK, Zipursky RB, Sagar HJ, Pfefferbaum A. A deficit profile of executive, memory, and motor functions in schizophrenia. Biol Psychiatry. 1994;36(10):641-653. doi:10.1016/0006-3223(94)91173-8

6. Wolff AL, O’Driscoll GA. Motor deficits and schizophrenia: the evidence from neuroleptic-naïve patients and populations at risk. J Psychiatry Neurosci. $1999 ; 24(4): 304-314$

7. Brébion G, Amador X, Smith M, Malaspina D, Sharif Z, Gorman JM. Depression, psychomotor retardation, negative symptoms, and memory in schizophrenia. 
medRxiv preprint doi: https://doi.org/10.1101/2020.07.20.20158287; this version posted July 25, 2020. The copyright holder for this preprint (which was not certified by peer review) is the author/funder, who has granted medRxiv a license to display the preprint in perpetuity.

All rights reserved. No reuse allowed without permission.

Neuropsychiatry Neuropsychol Behav Neurol. 2000;13(3):177-183.

8. Winograd-Gurvich C, Fitzgerald PB, Georgiou-Karistianis N, Bradshaw JL, White OB. Negative symptoms: A review of schizophrenia, melancholic depression and Parkinson's disease. Brain Res Bull. 2006;70(4):312-321. doi:10.1016/j.brainresbull.2006.06.007

9. Maes M, Sirivichayakul S, Kanchanatawan B, Carvalho AF. In schizophrenia, psychomotor retardation is associated with executive and memory impairments, negative and psychotic symptoms, neurotoxic immune products and lower natural IgM to malondialdehyde. World J Biol Psychiatry Off J World Fed Soc Biol Psychiatry. Published online February 7, 2020:1-19. doi:10.1080/15622975.2019.1701203

10. Kay SR, Opler LA. L-dopa in the treatment of negative schizophrenic symptoms: a single-subject experimental study. Int J Psychiatry Med. 1985;15(3):293-298. doi:10.2190/lmel-15hq-peqv-vycj

11. Bervoets C, Docx L, Sabbe B, et al. The nature of the relationship of psychomotor slowing with negative symptomatology in schizophrenia. Cognit Neuropsychiatry. 2014;19(1):36-46. doi:10.1080/13546805.2013.779578

12. Blanchard JJ, Kring AM, Horan WP, Gur R. Toward the next generation of negative symptom assessments: the collaboration to advance negative symptom assessment in schizophrenia. Schizophr Bull. 2011;37(2):291-299. doi:10.1093/schbul/sbq104

13. Kay SR. Positive-negative symptom assessment in schizophrenia: Psychometric issues and scale comparison. Psychiatr Q. 1990;61(3):163-178. doi:10.1007/BF01064966

14. Wilk CM, Gold JM, Humber K, Dickerson F, Fenton WS, Buchanan RW. Brief cognitive assessment in schizophrenia: normative data for the Repeatable Battery for the Assessment 
medRxiv preprint doi: https://doi.org/10.1101/2020.07.20.20158287; this version posted July 25, 2020. The copyright holder for this preprint (which was not certified by peer review) is the author/funder, who has granted medRxiv a license to display the preprint in perpetuity.

of Neuropsychological Status. Schizophr Res. 2004;70(2-3):175-186.

doi:10.1016/j.schres.2003.10.009

15. Jahn T, Cohen R, Hubmann W, et al. The Brief Motor Scale (BMS) for the assessment of motor soft signs in schizophrenic psychoses and other psychiatric disorders. Psychiatry Res. 2006;142(2-3):177-189. doi:10.1016/j.psychres.2002.12.002

16. Minassian A, Henry BL, Geyer MA, Paulus MP, Young JW, Perry W. The quantitative assessment of motor activity in mania and schizophrenia. $J$ Affect Disord. 2010;120(1-3):200-206. doi:10.1016/j.jad.2009.04.018

17. Walther S, Strik W. Motor symptoms and schizophrenia. Neuropsychobiology. 2012;66(2):77-92. doi:10.1159/000339456

18. Erhart SM, Marder SR, Carpenter WT. Treatment of schizophrenia negative symptoms: future prospects. Schizophr Bull. 2006;32(2):234-237. doi:10.1093/schbul/sbj055

19. Fusar-Poli P, Papanastasiou E, Stahl D, et al. Treatments of Negative Symptoms in Schizophrenia: Meta-Analysis of 168 Randomized Placebo-Controlled Trials. Schizophr Bull. 2015;41(4):892-899. doi:10.1093/schbul/sbu170

20. Millan MJ, Fone K, Steckler T, Horan WP. Negative symptoms of schizophrenia: clinical characteristics, pathophysiological substrates, experimental models and prospects for improved treatment. Eur Neuropsychopharmacol J Eur Coll Neuropsychopharmacol. 2014;24(5):645-692. doi:10.1016/j.euroneuro.2014.03.008

21. Singh SP, Singh V, Kar N, Chan K. Efficacy of antidepressants in treating the negative symptoms of chronic schizophrenia: meta-analysis. Br J Psychiatry J Ment Sci. 2010;197(3):174-179. doi:10.1192/bjp.bp.109.067710 
medRxiv preprint doi: https://doi.org/10.1101/2020.07.20.20158287; this version posted July 25, 2020. The copyright holder for this preprint (which was not certified by peer review) is the author/funder, who has granted medRxiv a license to display the preprint in perpetuity.

All rights reserved. No reuse allowed without permission.

22. Kirkpatrick B, Fenton WS, Carpenter WT, Marder SR. The NIMH-MATRICS Consensus Statement on Negative Symptoms. Schizophr Bull. 2006;32(2):214-219. doi:10.1093/schbul/sbj053

23. King DJ. Drug treatment of the negative symptoms of schizophrenia. Eur Neuropsychopharmacol J Eur Coll Neuropsychopharmacol. 1998;8(1):33-42. doi:10.1016/s0924-977x(97)00041-2

24. Möller H-J. Clinical evaluation of negative symptoms in schizophrenia. Eur Psychiatry J Assoc Eur Psychiatr. 2007;22(6):380-386. doi:10.1016/j.eurpsy.2007.03.010

25. Prikryl R, Kasparek T, Skotakova S, Ustohal L, Kucerova H, Ceskova E. Treatment of negative symptoms of schizophrenia using repetitive transcranial magnetic stimulation in a double-blind, randomized controlled study. Schizophr Res. 2007;95(1-3):151-157. doi:10.1016/j.schres.2007.06.019

26. Walther S, Koschorke P, Horn H, Strik W. Objectively measured motor activity in schizophrenia challenges the validity of expert ratings. Psychiatry Res. 2009;169(3):187-190. doi:10.1016/j.psychres.2008.06.020

27. Brown K, White T, Palmer D. Movement disorders and psychological tests of frontal lobe function in schizophrenic patients. Psychol Med. 1992;22:69-77.

28. Manschreck TC, Maher BA, Rucklos ME, Veneer Jr. DR, Ader DN. Deficient motor synchrony in schizophrenia. J Abnorm Psychol. 1981;90(4):321-328. doi:10.1037/0021-843X.90.4.321

29. Manschreck TC, Maher BA, Waller NG, Ames D, Latham CA. Deficient motor synchrony in schizophrenic disorders: Clinical correlates. Biol Psychiatry. 1985;20(9):990-1002. 
medRxiv preprint doi: https://doi.org/10.1101/2020.07.20.20158287; this version posted July 25, 2020. The copyright holder for this preprint (which was not certified by peer review) is the author/funder, who has granted medRxiv a license to display the preprint in perpetuity.

doi:10.1016/0006-3223(85)90197-0

30. Steffy R, Waldman I. Schizophrenics' reaction time: north star or shooting star? In: Schizophrenia Origins, Processes, Treatment, and Outcome. Cromwell R, Snyder C, editors. Oxford University Press; 1993:111-134.

31. Vrtunski PB, Simpson DM, Meltzer HY. Voluntary movement dysfunction in schizophrenics. Biol Psychiatry. 1989;25(5):529-539. doi:10.1016/0006-3223(89)90213-8

32. Walther S, Horn H, Razavi N, Koschorke P, Müller TJ, Strik W. Quantitative Motor Activity Differentiates Schizophrenia Subtypes. Neuropsychobiology. 2009;60(2):80-86. doi: $10.1159 / 000236448$

33. Insel TR. Digital phenotyping: a global tool for psychiatry. World Psychiatry. 2018;17(3):276-277. doi:10.1002/wps.20550

34. Alvino C, Kohler C, Barrett F, Gur RE, Gur RC, Verma R. Computerized measurement of facial expression of emotions in schizophrenia. J Neurosci Methods. 2007;163(2):350-361. doi:10.1016/j.jneumeth.2007.03.002

35. Dudek A, Wilczyński KM, Krysta K, et al. Analysis of facial expressions in patients with schziophrenia, in comparison with a healthy control - case study. Psychiatr Danub. 2017;29(Suppl 3):584-589.

36. Gaebel W, Wölwer W. Facial expressivity in the course of schizophrenia and depression. Eur Arch Psychiatry Clin Neurosci. 2004;254(5):335-342. doi:10.1007/s00406-004-0510-5

37. Jian B-L, Chen C-L, Chu W-L, Huang M-W. The facial expression of schizophrenic patients applied with infrared thermal facial image sequence. BMC Psychiatry. 2017;17(1):229. doi:10.1186/s12888-017-1387-y 
medRxiv preprint doi: https://doi.org/10.1101/2020.07.20.20158287; this version posted July 25, 2020. The copyright holder for this preprint (which was not certified by peer review) is the author/funder, who has granted medRxiv a license to display the preprint in perpetuity.

All rights reserved. No reuse allowed without permission.

38. Thevenot J, Lopez MB, Hadid A. A Survey on Computer Vision for Assistive Medical Diagnosis From Faces. IEEE J Biomed Health Inform. 2018;22(5):1497-1511. doi:10.1109/JBHI.2017.2754861

39. Opler MGA, Yavorsky C, Daniel DG. Positive and Negative Syndrome Scale (PANSS) Training: Challenges, Solutions, and Future Directions. Innov Clin Neurosci. 2017;14(11-12):77-81.

40. Baltrusaitis T, Robinson P, Morency L-P. OpenFace: An open source facial behavior analysis toolkit. In: 2016 IEEE Winter Conference on Applications of Computer Vision (WACV). IEEE; 2016:1-10. doi:10.1109/WACV.2016.7477553

41. Amos B, Ludwiczuk B, Satyanarayanan M. OpenFace: A general-purpose face recognition library with mobile applications. :20.

42. Baltrusaitis T, Zadeh A, Lim YC, Morency L-P. OpenFace 2.0: Facial Behavior Analysis Toolkit. In: 2018 13th IEEE International Conference on Automatic Face Gesture Recognition (FG 2018). ; 2018:59-66. doi:10.1109/FG.2018.00019

43. Jogems-Kosterman BJM, Zitman FG, Van Hoof JJM, Hulstijn W. Psychomotor slowing and planning deficits in schizophrenia. Schizophr Res. 2001;48(2-3):317-333. doi:10.1016/S0920-9964(00)00097-9

44. van Hoof JJM, Jogems-Kosterman BJM, Sabbe BGC, Zitman FG, Hulstijn W. Differentiation of cognitive and motor slowing in the Digit Symbol Test (DST): differences between depression and schizophrenia. J Psychiatr Res. 1998;32(2):99-103. doi:10.1016/S0022-3956(98)00057-0

45. Morrens M, Hulstijn W, Sabbe B. Psychomotor Slowing in Schizophrenia. Schizophr Bull. 
medRxiv preprint doi: https://doi.org/10.1101/2020.07.20.20158287; this version posted July 25, 2020. The copyright holder for this preprint (which was not certified by peer review) is the author/funder, who has granted medRxiv a license to display the preprint in perpetuity.

2007;33(4):1038-1053. doi:10.1093/schbul/sb1051

46. Morrens M, Hulstijn W, Matton C, et al. Delineating psychomotor slowing from reduced processing speed in schizophrenia. Cognit Neuropsychiatry. 2008;13(6):457-471.

doi:10.1080/13546800802439312

47. Wang SM, Ouyang WC, Wu MY, Kuo LC. Relationship between motor function and psychotic symptomatology in young-adult patients with schizophrenia. Eur Arch Psychiatry Clin Neurosci. 2020;270(3):373-382. doi:10.1007/s00406-019-01004-1

48. Javitt DC, Sweet RA. Auditory dysfunction in schizophrenia: integrating clinical and basic features. Nat Rev Neurosci. 2015;16(9):535-550. doi:10.1038/nrn4002

49. Kliper R, Vaizman Y, Weinshall D, Portuguese S. Evidence for depression and schizophrenia in speech prosody. In: ; 2019:85-88.

doi:10.36505/ExLing-2010/03/0022/000142

50. Martínez-Sánchez F, Muela-Martínez JA, Cortés-Soto P, et al. Can the Acoustic Analysis of Expressive Prosody Discriminate Schizophrenia? Span J Psychol. 2015;18:E86. doi:10.1017/sjp.2015.85

51. Parola A, Simonsen A, Bliksted V, Fusaroli R. Voice patterns in schizophrenia: A systematic review and Bayesian meta-analysis. Schizophr Res. 2020;216:24-40. doi:10.1016/j.schres.2019.11.031

52. Kayi ES, Diab M, Pauselli L, Compton M, Coppersmith G. Predictive Linguistic Features of Schizophrenia. ArXiv181009377 Cs. Published online October 22, 2018. Accessed May 29, 2020. http://arxiv.org/abs/1810.09377

53. Tahir Y, Yang Z, Chakraborty D, et al. Non-verbal speech cues as objective measures for 
medRxiv preprint doi: https://doi.org/10.1101/2020.07.20.20158287; this version posted July 25, 2020. The copyright holder for this preprint (which was not certified by peer review) is the author/funder, who has granted medRxiv a license to display the preprint in perpetuity.

All rights reserved. No reuse allowed without permission.

negative symptoms in patients with schizophrenia. PLOS ONE. 2019;14(4):e0214314.

doi:10.1371/journal.pone.0214314

54. Caligiuri MP, Ellwanger J. Motor and cognitive aspects of motor retardation in depression.

J Affect Disord. 2000;57(1-3):83-93. doi:10.1016/s0165-0327(99)00068-3

55. Szabadi E, Bradshaw CM, Besson JA. Elongation of pause-time in speech: a simple, objective measure of motor retardation in depression. Br J Psychiatry J Ment Sci.

1976;129:592-597. doi:10.1192/bjp.129.6.592

56. Sveinbjornsdottir S. The clinical symptoms of Parkinson's disease. J Neurochem. 2016;139 Suppl 1:318-324. doi:10.1111/jnc.13691

57. Bhat AN, Landa RJ, Galloway JC. Current perspectives on motor functioning in infants, children, and adults with autism spectrum disorders. Phys Ther. 2011;91(7):1116-1129. doi:10.2522/ptj.20100294

58. Rinehart NJ, Bellgrove MA, Tonge BJ, Brereton AV, Howells-Rankin D, Bradshaw JL. An examination of movement kinematics in young people with high-functioning autism and Asperger's disorder: further evidence for a motor planning deficit. J Autism Dev Disord. 2006;36(6):757-767. doi:10.1007/s10803-006-0118-x

59. Provost B, Lopez BR, Heimerl S. A Comparison of Motor Delays in Young Children: Autism Spectrum Disorder, Developmental Delay, and Developmental Concerns. J Autism Dev Disord. 2007;37(2):321-328. doi:10.1007/s10803-006-0170-6 


\section{Supplementary Materials}

Supplementary Table 1: Results for the multiple linear regressions conducted with head movement, age, and gender as predictors of individual items on the PANSS P subscale.

\begin{tabular}{|c|c|c|c|c|c|c|c|c|c|}
\hline Dependent variable & Predictor & Coefficient & $\begin{array}{l}\text { Std. } \\
\text { Err. }\end{array}$ & $\mathrm{t}$ & p-value & $\mathrm{F}$ & $\mathrm{R}^{2}$ & Adj. $R^{2}$ & $\mathrm{p}$-value \\
\hline P1 & & & & & & 4.494 & 0.491 & 0.381 & 0.0208 \\
\hline \multirow[t]{5}{*}{ Delusions } & Constant & 0.2849 & 0.212 & 1.341 & 0.201 & & & & \\
\hline & Head Motion & -0.4222 & 0.287 & -1.47 & 0.163 & & & & \\
\hline & Age & 0.0046 & 0.004 & 1 & 0.254 & & & & \\
\hline & Gender & 0.3453 & 0.102 & 1.190 & 0.005 & & & & \\
\hline & & & & 3.376 & & & & & \\
\hline P2 & & & & & & 3.928 & 0.457 & 0.341 & 0.0316 \\
\hline Conceptual & Constant & 0.5376 & 0.236 & 2.274 & 0.039 & & & & \\
\hline \multirow[t]{4}{*}{ disorganization } & Head Motion & -0.6582 & 0.319 & -2.06 & 0.058 & & & & \\
\hline & Age & 0.0014 & 0.004 & 2 & 0.750 & & & & \\
\hline & Gender & 0.3314 & 0.114 & 0.325 & 0.011 & & & & \\
\hline & & & & 2.911 & & & & & \\
\hline P3 & & & & & & 0.469 & 0.091 & -0.103 & 0.708 \\
\hline \multirow{5}{*}{ Hallucinatory behavior } & Constant & 0.2612 & 0.385 & 0.678 & 0.509 & 6 & & & \\
\hline & Head Motion & -0.0547 & 0.520 & -0.10 & 0.918 & & & & \\
\hline & Age & 0.0053 & 0.007 & 5 & 0.463 & & & & \\
\hline & Gender & 0.1843 & 0.185 & 0.755 & 0.337 & & & & \\
\hline & & & & 0.994 & & & & & \\
\hline P4 & & & & & & 1.196 & 0.204 & 0.033 & 0.347 \\
\hline \multirow[t]{5}{*}{ Excitement } & Constant & 0.4433 & 0.219 & 2.022 & 0.063 & & & & \\
\hline & Head Motion & 0.3482 & 0.296 & 1.176 & 0.259 & & & & \\
\hline & Age & -0.0039 & 0.004 & -0.96 & 0.353 & & & & \\
\hline & Gender & 0.0973 & 0.106 & 2 & 0.372 & & & & \\
\hline & & & & 0.921 & & & & & \\
\hline P5 & & & & & & 0.796 & 0.146 & -0.037 & 0.516 \\
\hline \multirow[t]{6}{*}{ Grandiosity } & Constant & 0.7971 & 0.271 & 2.946 & 0.011 & 5 & & & \\
\hline & Head Motion & -0.4925 & 0.365 & -1.34 & 0.199 & & & & \\
\hline & Age & -0.0037 & 0.005 & 8 & 0.467 & & & & \\
\hline & Gender & 0.0041 & 0.130 & -0.74 & 0.975 & & & & \\
\hline & & & & 8 & & & & & \\
\hline & & & & 0.032 & & & & & \\
\hline P6 & & & & & & 2.847 & 0.379 & 0.246 & 0.0755 \\
\hline \multirow[t]{6}{*}{ Suspiciousness } & Constant & 0.7946 & 0.214 & 3.721 & 0.002 & & & & \\
\hline & Head Motion & -0.2764 & 0.288 & -0.95 & 0.354 & & & & \\
\hline & Age & -0.0026 & 0.004 & 8 & 0.517 & & & & \\
\hline & Gender & 0.2735 & 0.103 & -0.66 & 0.019 & & & & \\
\hline & & & & 4 & & & & & \\
\hline & & & & 2.660 & & & & & \\
\hline P7 & & & & & & 0.654 & 0.123 & -0.065 & 0.593 \\
\hline \multirow[t]{5}{*}{ Hostility } & Constant & 0.4090 & 0.295 & 1.387 & 0.187 & 6 & & & \\
\hline & Head Motion & -0.5236 & 0.398 & -1.31 & 0.210 & & & & \\
\hline & Age & 0.0027 & 0.005 & 4 & 0.632 & & & & \\
\hline & Gender & 0.0339 & 0.142 & 0.489 & 0.815 & & & & \\
\hline & & & & 0.239 & & & & & \\
\hline
\end{tabular}


Supplementary Table 2: Results for the multiple linear regressions conducted with head movement, age, and gender as predictors of individual items on the PANSS N subscale

\begin{tabular}{|c|c|c|c|c|c|c|c|c|c|}
\hline Dependent variable & Predictor & Coefficient & Std. Err. & $\mathrm{t}$ & p-value & $\mathrm{F}$ & $\mathrm{R}^{2}$ & $\begin{array}{l}\text { Adj. } \\
\mathrm{R}^{2}\end{array}$ & p-value \\
\hline N1 & & & & & & 3.064 & 0.396 & 0.267 & 0.0629 \\
\hline Blunted & Constant & 0.5700 & 0.226 & 2.517 & 0.025 & & & & \\
\hline \multirow[t]{3}{*}{ Affect } & Head Motion & -0.7412 & 0.306 & -2.424 & 0.029 & & & & \\
\hline & Age & 0.0041 & 0.004 & 0.997 & 0.336 & & & & \\
\hline & Gender & 0.2000 & 0.109 & 0.997 & 0.088 & & & & \\
\hline N2 & & & & & & 4.313 & 0.480 & 0.369 & 0.0237 \\
\hline \multirow{4}{*}{ Emotional Withdrawal } & Constant & & 0.191 & 2.911 & 0.001 & & & & \\
\hline & Head Motion & 0.5566 & 0.258 & -2.898 & 0.012 & & & & \\
\hline & Age & $\begin{array}{r}-0.7483 \\
0.0050\end{array}$ & 0.004 & 1.690 & 0.113 & & & & \\
\hline & Gender & $\begin{array}{l}0.0059 \\
0.1604\end{array}$ & 0.092 & 1.742 & 0.103 & & & & \\
\hline $\mathbf{N 3}$ & & & & & & 2.395 & 0.339 & 0.198 & 0.112 \\
\hline \multirow[t]{4}{*}{ Poor Rapport } & Constant & 0.6747 & 0.237 & 2.843 & 0.013 & & & & \\
\hline & Head Motion & -0.7986 & 0.321 & -2.491 & 0.026 & & & & \\
\hline & Age & -0.0010 & 0.004 & -0.234 & 0.818 & & & & \\
\hline & Gender & 0.1294 & 0.114 & 1.133 & 0.276 & & & & \\
\hline N4 & & & & & & 1.761 & 0.274 & 0.118 & 0.201 \\
\hline \multirow{4}{*}{$\begin{array}{l}\text { Passive/apathetic social } \\
\text { withdrawal }\end{array}$} & Constant & 0.3798 & 0.229 & 1.655 & 0.120 & & & & \\
\hline & Head Motion & -0.4349 & 0.310 & -1.403 & 0.182 & & & & \\
\hline & Age & 0.0052 & 0.004 & 1.236 & 0.237 & & & & \\
\hline & Gender & 0.1754 & 0.111 & 1.588 & 0.135 & & & & \\
\hline N5 & & & & & & 1.546 & 0.249 & 0.088 & 0.247 \\
\hline \multirow[t]{4}{*}{ Difficulty in abstract thinking } & Constant & 0.5441 & 0.332 & 1.638 & 0.124 & & & & \\
\hline & Head Motion & -0.0918 & 0.449 & -0.205 & 0.841 & & & & \\
\hline & Age & -0.0014 & 0.006 & 0.227 & 0.824 & & & & \\
\hline & Gender & 0.3444 & 0.160 & 2.153 & 0.049 & & & & \\
\hline N6 & & & & & & 1.181 & 0.202 & 0.031 & 0.353 \\
\hline \multirow{4}{*}{$\begin{array}{l}\text { Lack of spontaneity \& flow of } \\
\text { conversation }\end{array}$} & Constant & 0.5248 & 0.295 & 1.780 & 0.097 & & & & \\
\hline & Head Motion & -0.6833 & 0.398 & -1.716 & 0.108 & & & & \\
\hline & Age & 0.0018 & 0.005 & 0.330 & 0.746 & & & & \\
\hline & Gender & 0.1249 & 0.142 & 0.880 & 0.394 & & & & \\
\hline N7 & & & & & & 2.991 & 0.391 & 0.260 & 0.0668 \\
\hline \multirow{4}{*}{ Stereotyped thinking } & Constant & 0.4336 & 0.233 & 1.859 & 0.084 & & & & \\
\hline & Head Motion & -0.5788 & 0.315 & -1.837 & 0.088 & & & & \\
\hline & Age & 0.0053 & 0.004 & 1.238 & 0.236 & & & & \\
\hline & Gender & 0.2580 & 0.112 & 2.297 & 0.038 & & & & \\
\hline
\end{tabular}


Supplementary Table 3: Results for the multiple linear regressions conducted with head movement, age, and gender as predictors of individual items on the PANSS G subscale

\begin{tabular}{|c|c|c|c|c|c|c|c|c|c|}
\hline Dependent variable & Predictor & Coefficient & Std. Err. & $\mathrm{t}$ & $\mathrm{p}$-value & $\mathrm{F}$ & $\mathrm{R}^{2}$ & Adj. $\mathrm{R}^{2}$ & $\mathrm{p}$-value \\
\hline G1 & & & & & & 0.2899 & 0.058 & -0.143 & 0.832 \\
\hline \multirow[t]{4}{*}{ Somatic concern } & Constant & 0.4109 & 0.292 & 1.409 & 0.181 & & & & \\
\hline & Head Motion & -0.1828 & 0.394 & -0.464 & 0.650 & & & & \\
\hline & Age & 0.0042 & 0.005 & 0.786 & 0.445 & & & & \\
\hline & Gender & -0.0104 & 0.140 & -0.074 & 0.942 & & & & \\
\hline G2 & & & & & & 0.1293 & 0.027 & -0.182 & 0.941 \\
\hline \multirow[t]{4}{*}{ Anxiety } & Constant & 0.5268 & 0.288 & 1.827 & 0.089 & & & & \\
\hline & Head Motion & -0.0462 & 0.390 & -0.119 & 0.907 & & & & \\
\hline & Age & -0.0006 & 0.005 & -0.105 & 0.918 & & & & \\
\hline & Gender & 0.1604 & 0.092 & 1.742 & 0.103 & & & & \\
\hline G3 & & & & & & 1.880 & 0.287 & 0.134 & 0.179 \\
\hline \multirow[t]{4}{*}{ Guilt feelings } & Constant & 0.2955 & 0.278 & 1.064 & 0.305 & & & & \\
\hline & Head Motion & -0.2447 & 0.375 & -0.652 & 0.525 & & & & \\
\hline & Age & 0.0014 & 0.005 & 0.271 & 0.790 & & & & \\
\hline & Gender & 0.3117 & 0.134 & 2.331 & 0.035 & & & & \\
\hline G4 & & & & & & 5.333 & 0.533 & 0.433 & 0.0116 \\
\hline \multirow[t]{4}{*}{ Tensions } & Constant & 0.5464 & 0.161 & 3.390 & 0.004 & & & & \\
\hline & Head Motion & -0.2114 & 0.218 & -0.971 & 0.348 & & & & \\
\hline & Age & -0.0050 & 0.003 & -1.698 & 0.112 & & & & \\
\hline & Gender & 0.2597 & 0.078 & 3.346 & 0.005 & & & & \\
\hline G5 & & & & & & 2.692 & 0.366 & 0.230 & 0.0862 \\
\hline \multirow[t]{4}{*}{ Mannerisms } & Constant & 0.3047 & 0.198 & 1.537 & 0.147 & & & & \\
\hline & Head Motion & -0.4734 & 0.268 & -1.768 & 0.099 & & & & \\
\hline & Age & 0.0039 & 0.004 & 1.068 & 0.304 & & & & \\
\hline & Gender & 0.2107 & 0.095 & 2.207 & 0.045 & & & & \\
\hline G6 & & & & & & 1.030 & 0.181 & 0.005 & .409 \\
\hline \multirow[t]{4}{*}{ Depression } & Constant & 0.8704 & 0.294 & 2.963 & 0.010 & & & & \\
\hline & Head Motion & -0.3390 & 0.397 & -0.855 & 0.407 & & & & \\
\hline & Age & -0.0071 & 0.005 & -1.313 & 0.210 & & & & \\
\hline & Gender & 0.1001 & 0.141 & 0.708 & 0.491 & & & & \\
\hline G7 & & & & & & 4.023 & 0.463 & 0.348 & 0.0294 \\
\hline \multirow{4}{*}{$\begin{array}{l}\text { Motor } \\
\text { retardation }\end{array}$} & Constant & 0.6199 & 0.243 & 2.554 & 0.023 & & & & \\
\hline & Head Motion & -1.0616 & 0.328 & -3.239 & 0.006 & & & & \\
\hline & Age & 0.0050 & 0.004 & 1.127 & 0.279 & & & & \\
\hline & Gender & 0.1160 & 0.117 & 0.992 & 0.338 & & & & \\
\hline \multirow{5}{*}{$\begin{array}{l}\text { G8 } \\
\text { Uncooperativeness }\end{array}$} & & & & & & 2.190 & 0.319 & 0.174 & 0.135 \\
\hline & Constant & 0.7052 & 0.224 & 3.154 & 0.007 & & & & \\
\hline & Head Motion & -0.6850 & 0.302 & -2.269 & 0.040 & & & & \\
\hline & Age & -0.0019 & 0.004 & -0.455 & 0.656 & & & & \\
\hline & Gender & 0.1322 & 0.108 & 1.228 & 0.240 & & & & \\
\hline \multirow{5}{*}{$\begin{array}{l}\text { G9 } \\
\text { Unusual thought } \\
\text { content }\end{array}$} & & & & & & 1.161 & 0.199 & 0.028 & 0.359 \\
\hline & Constant & 0.3177 & 0.269 & 1.179 & 0.258 & & & & \\
\hline & Head Motion & -0.3157 & 0.364 & -0.867 & 0.400 & & & & \\
\hline & Age & 0.0048 & 0.005 & 0.969 & 0.349 & & & & \\
\hline & Gender & 0.1960 & 0.130 & 1.510 & 0.153 & & & & \\
\hline
\end{tabular}


medRxiv preprint doi: https://doi.org/10.1101/2020.07.20.20158287; this version posted July $25,2020$. The copyright holder for this preprint (which was not certified by peer review) is the author/funder, who has granted medRxiv a license to display the preprint in perpetuity. All rights reserved. No reuse allowed without permission.

\begin{tabular}{|c|c|c|c|c|c|c|c|c|c|}
\hline \multirow{5}{*}{$\begin{array}{l}\text { G10 } \\
\text { Disorientation }\end{array}$} & & & & & & \multirow[t]{5}{*}{2.254} & \multirow[t]{5}{*}{0.326} & \multirow[t]{5}{*}{0.181} & \multirow[t]{5}{*}{0.127} \\
\hline & Constant & 0.7891 & 0.323 & 2.441 & 0.029 & & & & \\
\hline & Head Motion & -0.6056 & 0.437 & -1.387 & 0.187 & & & & \\
\hline & Age & -0.0012 & 0.006 & -0.198 & 0.846 & & & & \\
\hline & Gender & 0.3526 & 0.156 & 2.264 & 0.040 & & & & \\
\hline \multirow{5}{*}{$\begin{array}{l}\text { G11 } \\
\text { Poor attention }\end{array}$} & & & & & & 4.494 & 0.491 & 0.381 & 0.0208 \\
\hline & Constant & 0.4041 & 0.203 & 1.992 & 0.066 & & & & \\
\hline & Head Motion & -0.4899 & 0.274 & -1.788 & 0.095 & & & & \\
\hline & Age & 0.0009 & 0.004 & 0.233 & 0.819 & & & & \\
\hline & Gender & 0.3269 & 0.098 & 3.345 & 0.005 & & & & \\
\hline \multirow{5}{*}{$\begin{array}{l}\text { G12 } \\
\text { Lack of judgement and } \\
\text { insight }\end{array}$} & & & & & & 3.069 & 0.397 & 0.267 & 0.0626 \\
\hline & Constant & 0.4446 & 0.230 & 1.937 & 0.073 & & & & \\
\hline & Head Motion & -0.7751 & 0.310 & -2.500 & 0.025 & & & & \\
\hline & Age & 0.0060 & 0.004 & 1.414 & 0.179 & & & & \\
\hline & Gender & -0.0687 & 0.111 & -0.622 & 0.544 & & & & \\
\hline \multirow{5}{*}{$\begin{array}{l}\text { G13 } \\
\text { Disturbance of volition }\end{array}$} & & & & & & 5.521 & 0.542 & 0.444 & 0.0103 \\
\hline & Constant & 0.3846 & 0.177 & 2.170 & 0.048 & & & & \\
\hline & Head Motion & -0.4825 & 0.239 & -2.016 & 0.063 & & & & \\
\hline & Age & 0.0049 & 0.003 & 1.513 & 0.153 & & & & \\
\hline & Gender & 0.2994 & 0.085 & 3.509 & 0.003 & & & & \\
\hline \multirow{5}{*}{$\begin{array}{l}\text { G14 } \\
\text { Poor impulse control }\end{array}$} & & & & & & 0.4756 & 0.092 & -0.102 & 0.704 \\
\hline & Constant & 0.3821 & 0.271 & 1.411 & 0.180 & & & & \\
\hline & Head Motion & -0.2354 & 0.366 & -0.643 & 0.530 & & & & \\
\hline & Age & 0.0044 & 0.005 & 0.890 & 0.389 & & & & \\
\hline & Gender & 0.0816 & 0.130 & 0.626 & 0.541 & & & & \\
\hline \multirow{5}{*}{$\begin{array}{l}\text { G15 } \\
\text { Preoccupation }\end{array}$} & & & & & & 5.089 & 0.522 & 0.419 & 0.0137 \\
\hline & Constant & 0.2763 & 0.214 & 1.289 & 0.218 & & & & \\
\hline & Head Motion & -0.5410 & 0.290 & -1.868 & 0.083 & & & & \\
\hline & Age & 0.0074 & 0.004 & 1.879 & 0.081 & & & & \\
\hline & Gender & 0.3322 & 0.103 & 3.217 & 0.006 & & & & \\
\hline \multirow{5}{*}{$\begin{array}{l}\text { G16 } \\
\text { Active social avoidance }\end{array}$} & & & & & & 0.6738 & 0.126 & -0.061 & 0.582 \\
\hline & Constant & 0.3332 & 0.241 & 1.385 & 0.188 & & & & \\
\hline & Head Motion & 0.0373 & 0.325 & 0.115 & 0.910 & & & & \\
\hline & Age & 0.0046 & 0.004 & 1.040 & 0.316 & & & & \\
\hline & Gender & 0.1226 & 0.116 & 1.058 & 0.308 & & & & \\
\hline
\end{tabular}


medRxiv preprint doi: https://doi.org/10.1101/2020.07.20.20158287; this version posted July 25, 2020. The copyright holder for this preprint

(which was not certified by peer review) is the author/funder, who has granted medRxiv a license to display the preprint in perpetuity.

All rights reserved. No reuse allowed without permission.

\section{Declaration of Interest}

Dr. Perez-Rodriguez has received research grant funding from Neurocrine Biosciences (Inc),

Millennium Pharmaceuticals, Takeda, Merck, and AiCure; She is an Advisory Board member for

Neurocrine Biosciences, Inc, and a consultant on an American Foundation for Suicide Prevention

(AFSP) grant (LSRG-1-005-16, PI: Baca-Garcia)

Authors Anzar Abbas, Vijay Yadav, Vidya Koesmahargyo, Li Zhang, and Isaac Galatzer-Levy are employed at AiCure and own shares or are eligible to own shares in AiCure.

This study was funded by AiCure LLC (Protocol \# AICVDX01), GCO\#: 18-0968-00001-01-PD. 